\title{
Susceptibility assessment to different types of landslides in the coastal cliffs of Lourinhã (Central Portugal)
}

\author{
Bruno Epifânio ${ }^{\mathrm{a}, *}$, José Luís Zêzere ${ }^{\mathrm{b}}$, Mário Neves ${ }^{\mathrm{b}}$ \\ a Instituto de Geografia e Ordenamento do Território, Universidade de Lisboa, Avenida Prof. Gama Pinto, 1649-003 Lisboa, Portugal

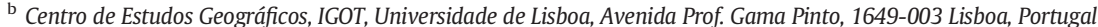

\section{A R T I C L E I N F O}

\section{Article history:}

Received 27 May 2013

Received in revised form 6 March 2014

Accepted 16 April 2014

Available online 26 April 2014

\section{Keywords:}

Coastal Cliffs

Landslides

Susceptibility

Information Value

Portuguese Western Coast

\begin{abstract}
A B S T R A C T
The coastal zone of Lourinhã (located in Central Portugal) is characterized by beach-cliff systems, where beaches are narrow and cliffs have notorious slope instability. These cliffs evolve by different types of landslides, which are one of the main sources of natural hazard and risk in this coastal region.

In this work, aerial photo interpretation and a systematic field survey were performed in order to obtain an inventory of landslides of the following types: rotational slides, translational slides and debris flows. The entire coast was then split into 261 terrain mapping units. For each unit, landslide predisposing factors were derived and classified: cliff elevation, slope angle (maximum, mean and standard deviation), potential solar radiation, slope curvature (profile and plan), lithological units and geologic structure. The predictive susceptibility models were computed for each type of landslide using a bi-variate statistical method - the Information Value Method. The degree of fit and the predictive capacity of the models were assessed using the Effectiveness Ratio, the standard Receiver Operator Characteristic curves and the respective Area Under Curve.

Results show that each landslide typology occurs in particular terrain conditions. Individual susceptibility models evidence better predictive capacity than susceptibility model for total landslides.
\end{abstract}

(c) 2014 Elsevier B.V. All rights reserved.

\section{Introduction}

The evolution of coastal cliffs occurs mainly by landslides of different types and sizes, resulting from the interaction of marine, sub-aerial and anthropogenic processes (Greenwood and Orford, 2007). In consequence, this complex and dynamic evolution introduces restrictions on the way the human occupation of coastal areas is accomplished (Marques, 2009).

In general, research on hazard assessment in coastal cliffs focuses on retreat rate evaluation (e.g. Nunes et al., 2009). In addition, the role of landslides in cliff evolution has been recognized worldwide (e.g. Hampton et al., 2004; Marques, 1997, 2009; Sunamura, 1992; Teixeira, 2006; Trenhaile, 1987). According to Neves and RamosPereira (1999), the identification of factors and processes which control the rocky coast system is a critical step to understand how this system is evolving and to predict its future evolution. Under the assumption of the uniformitarianism principle, knowing the set of predisposing factors that conditioned the location of past and present landslides, it is possible to predict where future landslides are more likely to occur (Varnes, 1984).

Different types of landslides may occur in coastal cliffs: falls, topples, slides and flows. The identification of each landslide type is complex to

\footnotetext{
* Corresponding author.

E-mail addresses: brunoe@campus.ul.pt (B. Epifânio), zezere@campus.ul.pt (J.L. Zêzere), marioneves@campus.ul.pt (M. Neves).
}

perform even with the support of intensive field work (Neves et al. 2012). Indeed, in very steep coastal cliffs the clear separation between the more frequent cliff failures is nearly impossible to perform in a systematic way, namely the separation between rockfalls, topples and steep shear plane planar slides. In such circumstances the detailed field work frequently does not enable a safe cliff instability classification because of the lack of clear field evidences. Moreover, in some cases the cliff face is not accessible. In contrast, the identification of the landslide type is easier to carry out in cliffs as those in the study area, which have relatively low slope angles and are dominated by landslides of slide and flow types.

The role of a set of predisposing factors to the activity of different types of landslides was discussed by Zêzere (2002). This author pointed out that different types of landslides may be related in a different way with the same set of landslide predisposing factors. Thus, when susceptibility models are performed using an assemblage of different types of landslides, results can lead to a decrease in correlation among landslides and predisposing factors (Zêzere, 2002). The spatial relationships between landslides which have already occurred in a certain area and the set of landslide predisposing factors are usually explored with data-driven methods in order to assess landslide susceptibility (e.g. Carrara et al., 1998; Epifânio et al., 2013; Guillard and Zêzere, 2012; Guzzetti et al., 2005; Zêzere et al., 2004). Besides the influence of the magnitude of wave action at the base of cliff, Sunamura (1992) 
points out the strong relationship existing between landslide occurrence and the geologic characteristics of coastal cliffs (lithology, geologic structure and geotechnical properties).

Statistical methods used to assess landslide susceptibility require a subdivision of territory in terrain mapping units. To select the appropriate terrain mapping unit (e.g. grid cells, terrain units, unique condition units, slope units, geo-hydrological units, topographic units, and political or administrative units (Van Den Eeckhaut et al., 2009)) the following factors must be considered (Guzzetti et al., 1999): (i) typology of landslides in analysis; (ii) working scale of the study; (iii) resolution, quality and type of thematic information; and (iv) availability of the adequate data and adjustment of the analysis tools.

Regardless of the type of selected mapping units, it is mandatory to homogenize the information inherent to each unit and, simultaneously, to guarantee the differentiation between adjacent mapping units (Guzzetti et al., 1999). In addition, the adoption of an appropriate mapping unit is essential because the different partitions interfere in the way data is integrated and treated into the modeling process (Guzzetti et al., 1999), thus generating different landslide susceptibility results (Carrara et al., 2008).

In inland areas (at the basin scale), very good results were obtained for predictive models of landslide susceptibility using a grid of cells (e.g. Guillard and Zêzere, 2012; Zêzere et al., 2004). However, in rocky coastal areas, this methodology is not suitable. The typical high slope and short extension that characterize most coastal cliffs do not generate a relevant topographic contrast that usually are to be found at the basin scale between stable and unstable areas and this is a reason for the bad performance of grid cells when assessing landslide susceptibility in coastal cliffs.

Recently, Marques et al. (2011, 2013) mentioned that all factors influencing the stability of coastal cliffs should be considered because they may contribute to future instability. This approach led to the adoption of methodologies that divide cliffs into terrain units. Conventionally, the boundaries of these terrain units were defined by the materials, landforms or geomorphological processes occurring in the study area (Guzzetti et al., 1999). In recent years, some authors have discussed the main advantage and drawbacks of different types of terrain mapping units (Van den Eeckhaut et al., 2009), and even highlighted the relevance of terrain units in the analysis and modeling of geological and environmental phenomena (Carrara et al., 2008). Although the needs to develop new methodologies to improve the predictive quality of the landslide susceptibility assessment at the cliffs are evident, the selection of adjusted terrain mapping units has not received yet special attention. Additionally, even if landslide susceptibility assessment proved to generate better results in inland basin areas when different landslide types are considered independently (e.g. Zêzere, 2002), little work has been done on this subject until now when assessing landslide susceptibility in coastal cliffs.

Therefore, the present paper aims: (i) to assess landslide susceptibility at coastal cliffs for different types of landslides (rotational slides, translational slides and debris flows); (ii) to use the same set of landslide predisposing factors and a single statistical method to weigh and integrate variables; (iii) to identify the most important predisposing variables that control the spatial distribution of different landslide types; and (iv) to compare landslide predictive models obtained for each landslide type and for the total landslide inventory.

\section{Study area}

The study area (Fig. 1) is located in a rocky coast in the center west of Portugal, specifically in the Lourinhã council. It is limited to the north and south by the council's area extent and east and west by cliff top and cliff toe, respectively.

The Lourinhã coastal area extends along $12.3 \mathrm{~km}$ and it is mainly faced to the west. The coastline has mainly a beach-cliff system with narrow and elongated beaches, and the cliff height ranges from 11 to
$84 \mathrm{~m}$, with higher values located in the southern part. This spatial variation is generically in accordance with the adjacent territory located inside of the council (Fig. 1). In some few places, coastal cliffs are intercepted by small rivers, mainly with ephemeral runoff.

The bedrock of the center west coast of Portugal is composed of Jurassic and Cretaceous rocks affected by gentle synclinal and anticlinal deformations (Fig. 2). Locally, coastal cliffs are cut on Jurassic rocks (Kimmeridgian and Tithonian ages) composed mainly of marl and sandstone topped by Quaternary sand (Fig. 3) (Manuppella et al., 1999). The sedimentary bed strike is approximately parallel to the coastline, with low to moderate dip (between 0 and $15^{\circ}$ ) to the north or south (Neves, 2004).

The west coast of Portugal has a semidiurnal mesotidal regime and is predominantly exposed to the NW wave regime (about $80 \%$ of recorded cases) with a time period (T) of 9-11 $\mathrm{s}$ and a significant wave height (Hs) of 2-2.5 $\mathrm{m}$, that can reach up to $6 \mathrm{~m}$ in storm situations (Pires, 1989). In the study area, the mean annual precipitation ranges from 600 to $700 \mathrm{~mm}$. Most rainfall occurs between November and March, but rainfall distribution may be highly irregular (Daveau, 1988). The mean annual temperature is $15^{\circ} \mathrm{C}$. The highest temperature values occur between July and September (Neves, 2004).

In this coastal zone, cliffs are affected by different types of landslides that are an important source of natural hazard and risk particularly to exposed elements (e.g. buildings) located near the cliff top.

\section{Data and methods}

\subsection{Landslide inventory}

The knowledge of the spatial distribution of past and present landslides, as well as the identification of their respective types, is crucial to assess landslide susceptibility. The information of landslides in the study area was integrated in a landslide inventory map. The landslide inventory which was created by photo-interpretation of digital orthophotos obtained in 2007 (pixel size $=0.5 \mathrm{~m}$ ) complemented with the interpretation of altimetry (contour lines 5 m equidistance) and by systematic field survey. Landslide boundaries were interpreted and drawn at a scale of $1 / 1500$, and later vectorized and stored in a GIS environment (ArcGIS 9.3.1 software). Field survey enabled the validation of the previously identified landslides and the addition to the inventory of new landslides not observed during the photointerpretation phase. Landslide typologies were assigned according to Varnes (1978), WP/WLI's (1993) and Dikau et al. (1996), and the following landslide types were identified: rotational slides, translational slides, and debris flows (Fig. 4). Rotational slide is the downward movement of rock or debris occurring over a concave slip surface that typically develops in isotropic and homogeneous geological materials (Varnes, 1978; Zêzere, 1997). In contrast, translational slide is a block movement along a planar slip surface that may disintegrate downslope (Cruden and Varnes, 1996). Finally, debris flow is the spatially continuous movement of debris material down a slope as a viscous fluid. The shear surfaces are closely spaced, ephemeral and not usually preserved leading to the internal deformation of materials (WL/WLI, 1993; Zêzere, 2005).

The final inventory of the study area is composed by 290 cliff failures: 64 rotational slides (22.1\%); 24 translational slides (8.3\%); and 202 debris flows (69.6\%). These landslides affected a total area of $141,957 \mathrm{~m}^{2}$, the rotational slides being the most representative $(72.7 \%$ of total landslide area), followed by debris flows (18.2\%), and translational slides (9.1\%).

\subsection{Terrain mapping units and landslide predisposing factors}

The application of any statistical method to assess landslide susceptibility requires the partition of the study area into smaller terrain units. Terrain units were drawn along the cliff top, following $50 \mathrm{~m}$ divisions of 

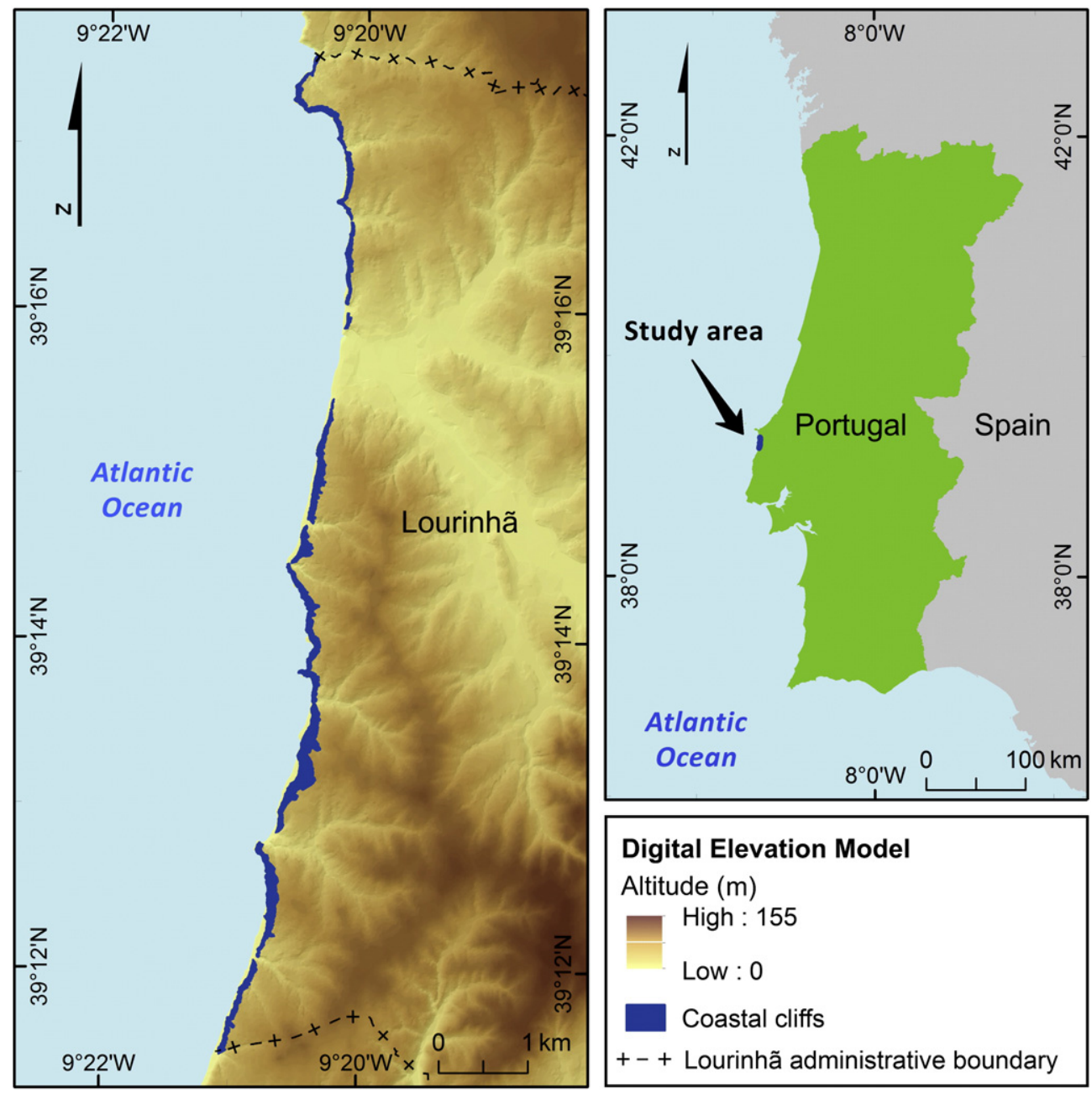

Fig. 1. Location of the coastal area of the Lourinhã council.

the cliff top contour (smoothed with a small radius of tolerance in mixed geomorphologic controls), as suggested by Marques et al. (2011, 2013), with the upper and lower limits matching, respectively, the cliff top and the cliff toe; the lateral limits are approximately perpendicular to the contour lines of the cliff face (Fig. 5). Thus, 261 terrain mapping units were created.

Landslide predisposing factors describe terrain conditions that are directly or indirectly associated with landslide occurrence. In a previous similar work on coastal cliffs, Marques et al. (2011) used the following set of predisposing factors: cliff height; mean cliff slope angle; maximum cliff slope angle; aspect; mean plan curvature of the cliff faces; mean cross profile curvature of the cliff faces; presence and type of cliff toe protection; presence of faults; lithological units; and geologic structure. It is important to point out that the selection of predisposing factors associated with the occurrence of landslides proves to be a difficult task since the factors work in combination, in a system that is typically multivariate. In addition, the physical forces that control the stability state of coastal cliffs (i.e. shear strength of rocks and soils and effective shear stress) are seldom available for large areas. Therefore, it is usual to use mappable variables that are proxy variables for the coastal cliff instability system.

In this study, two sets of landslide predisposing factors were considered: morphometric parameters and geological characteristics. Morphometric parameters include cliff elevation, maximum slope angle, mean slope angle, standard deviation of slope angle, profile slope curvature, plan slope curvature and potential solar radiation (which is a quantitative proxy variable for the slope aspect). Slope angle is considered the most important predisposing factor in the occurrence of landslides (Mancini et al., 2010) and reflects directly the shear stress that occurs in the cliffs. The standard deviation of slope angle is used to detect and quantify topographic irregularities at the cliff face. The cliff faces' curvatures influence the local drainage system and the kinematics of landslides (Mancini et al., 2010). The slope curvature expresses the acceleration and deceleration of the flow, as well as the convergence or divergence of the flow. In this study, the potential solar radiation is used as a proxy variable that quantifies the slope aspect because it enables the quantification of the weight of trivial qualitative quadrant. The complete set of morphometric factors were computed in ArcGIS 9.3.1. The morphometric information was extracted from a Digital Elevation Model (DEM) with a $5 \mathrm{~m}$ pixel size, created from contour lines with $5 \mathrm{~m}$ of equidistance and elevation points available in digital vector format. The exceptions are the profile and plan slope curvatures that were derived using a pixel size of $10 \mathrm{~m}$ because curvature values were not realistic at a highest resolution, i.e., the $5 \mathrm{~m}$ pixel is not suited to the scale of the geomorphic process that is evaluated. Geologic characteristics include lithological units and geologic structure (concerning the attitude of the sedimentary layers in relation to the coastline orientation). Lithological units were intended to give an indication of the key variables in the system of unstable slopes, such as shear strength, permeability and propensity for physical and chemical weathering of rock and soil materials (Varnes, 1984). Geologic structure is an important predisposing factor 


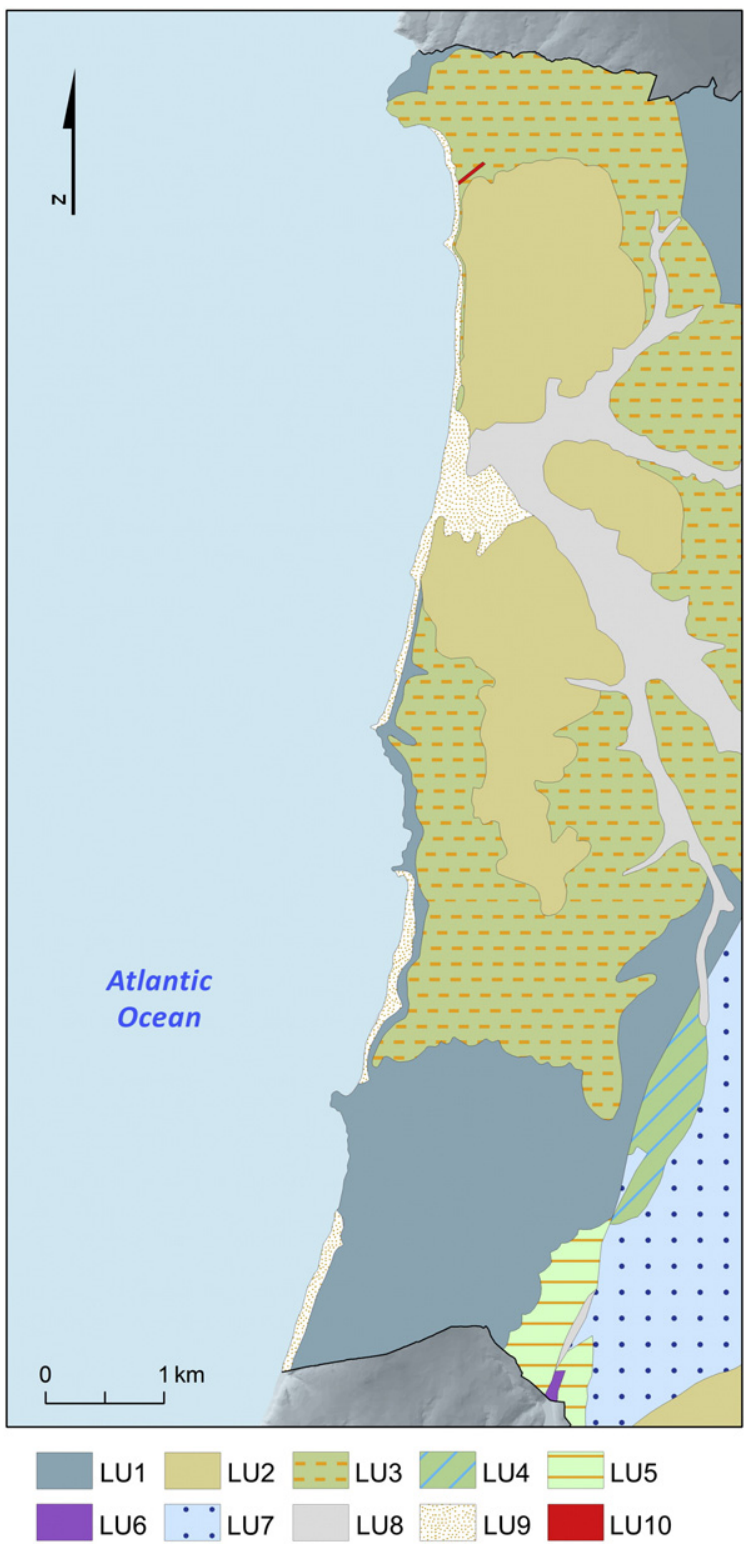

Fig. 2. Geologic map of the Lourinhã coastal area. Lithological units: LU1 - sandstone, marl and mudstone of Praia da Amoreira and Porto Novo; LU2 - sandstone, marl, clay and conglomerate of Bombarral; LU3 - marl, clay and sandstone of Sobral; LU4 - marl and sandstone of Nadrupe; LU5 - limestone of Vimeiro; LU6 - marl of Dagorda; LU7 marl and sandstone of Castelhano; LU8 - alluvium; LU9 - beach and dune sands; LU10 dolerite.

when associated with the cliff face orientation, concerning the definition of areas of weakness that can act as rupture plans. Lithological unit data was extracted from the Portuguese geological map covering the region at a scale of 1/50,000 (Manuppella et al., 1999), and the geologic structure was obtained from Neves (2004).

To apply a bi-variate statistical method, the classification of numerical continuous predisposing factors is required. In the case of morphometric parameters, class boundaries were defined in order to guarantee a minimum homogeneous distribution of terrain units and to avoid scale effects on the analysis of susceptibility. The geologic parameter classes were defined according to the available literature. Table 1 summarizes the 47 variable classes that were used as landslide predisposing factors.

The most relevant predisposing factors to produce landslide susceptibility models were identified using two estimators: Accountability (A) and Reliability (R). The Accountability evaluates the relative landslide
Stratigraphic Column

Lithological Units

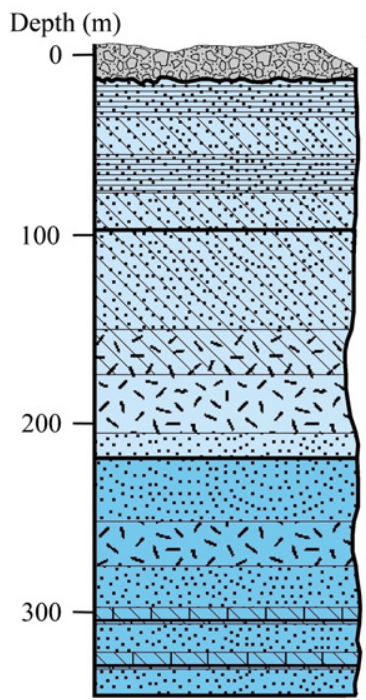

Sandstone, marl, clay and conglomerate of Bombarral

Marl, clay and sandstone of Sobral

Sandstone, marl and mudstone of Praia da Amoreira and Porto Novo

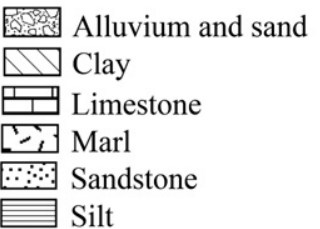

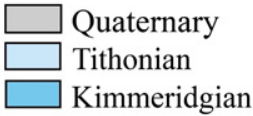

Fig. 3. Stratigraphic column for the Lourinhã coastal area. Data source - Manuppella et al. (1999).

concentration on the predisposing factor classes with the landslide density higher than the regional average (Blahut et al., 2010), through the following equation:

$\mathrm{A}=\frac{\sum \text { Nutsld } 1}{\sum \text { Nutsld }}$

where Nutdsld 1 is the number of unstable terrain units in those predisposing factor classes having a landslide density higher than the landslide density observed on the entire study area, and Nutsld is the total number of unstable terrain units on the study area.

The Reliability considers the density of landslides in predisposing factor classes which are most relevant to their occurrence (Blahut et al., 2010), according to the following equation:

$\mathrm{R}=\frac{\sum \text { Nutsld } 1}{\sum N u t c l s}$

where Nutcls is the total number of terrain units (stable and unstable) in those predisposing factor classes having a landslide density higher than the landslide density observed on the entire study area. According to Blahut et al. (2010), the Accountability index explains how classes of predisposing map that are relevant for the analysis correlate with landslides, while the Reliability index indicates the average landslide density in classes of predisposing factors more prone to landslide occurrence.

Terrain mapping units were classified according to stability conditions, following the approach proposed by Guzzetti et al. (2005). This classification was based on the type of cliff instability and percentage of unstable area: if the area affected by rotational (translational) slides exceeds $2.0 \%$ of the total area of the terrain unit, then, the terrain unit was considered unstable regarding rotational (translational) slides. The indicative percentage value to consider a terrain unit unstable is reduced to $0.5 \%$ of the total area of the terrain unit for debris flows because 

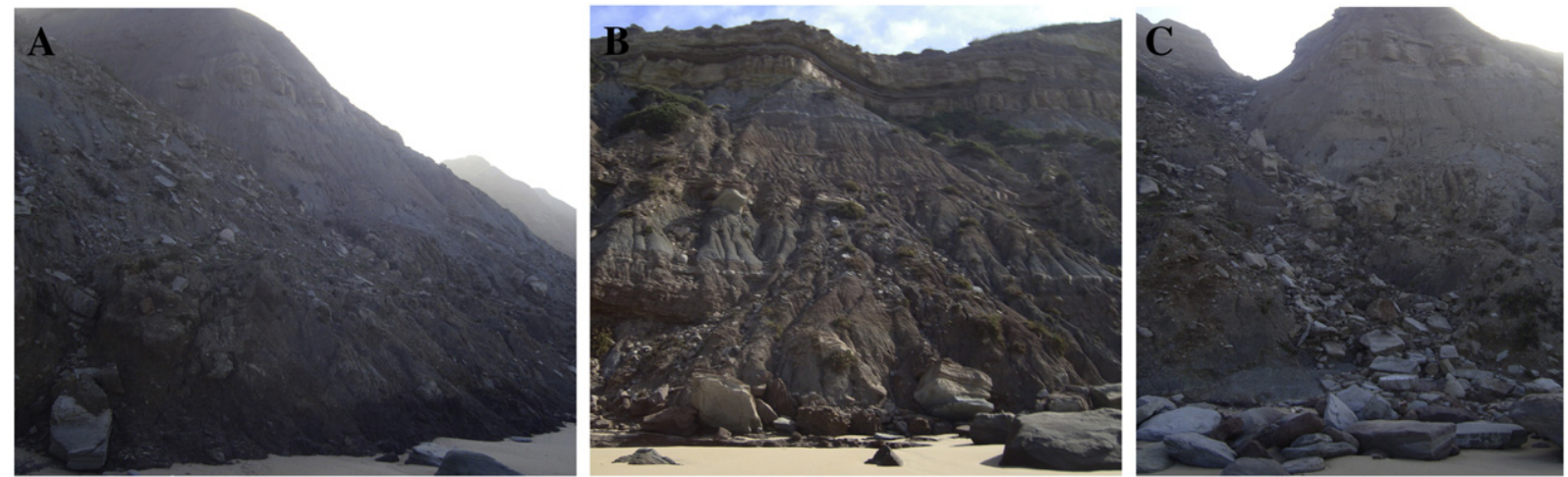

Fig. 4. Examples of landslides in the study area. A - rotational slide; B - translational slide; C - debris flow.

of the typical small size of these slope movements in the study area. The terrain units not matching the abovementioned conditions were considered stable. These threshold values were used to account for possible errors (e.g. drafting, mapping and digitizing errors) in the elaboration of the landslide inventory map, taking in consideration the relationship between the landslide affected area and the corresponding terrain unit area. In the study area, rotational slides affect on average $66.4 \%$ of the terrain unit area and the equivalent features for translational slides and debris flows are $21.8 \%$ and $5.2 \%$, respectively. In total, it was possible to identify 92 unstable terrain units with rotational slides (35.2\% of total terrain units), 28 unstable terrain units with translational slides (10.7\%), 143 unstable terrain units with debris flow (54.8\%) and 209 unstable terrain units with any landslide type inventoried (80.1\%). For modeling purposes, each group of unstable terrain units (considered for each landslide typology) was randomly split into two sub-sets: the modeling set and the validation set.

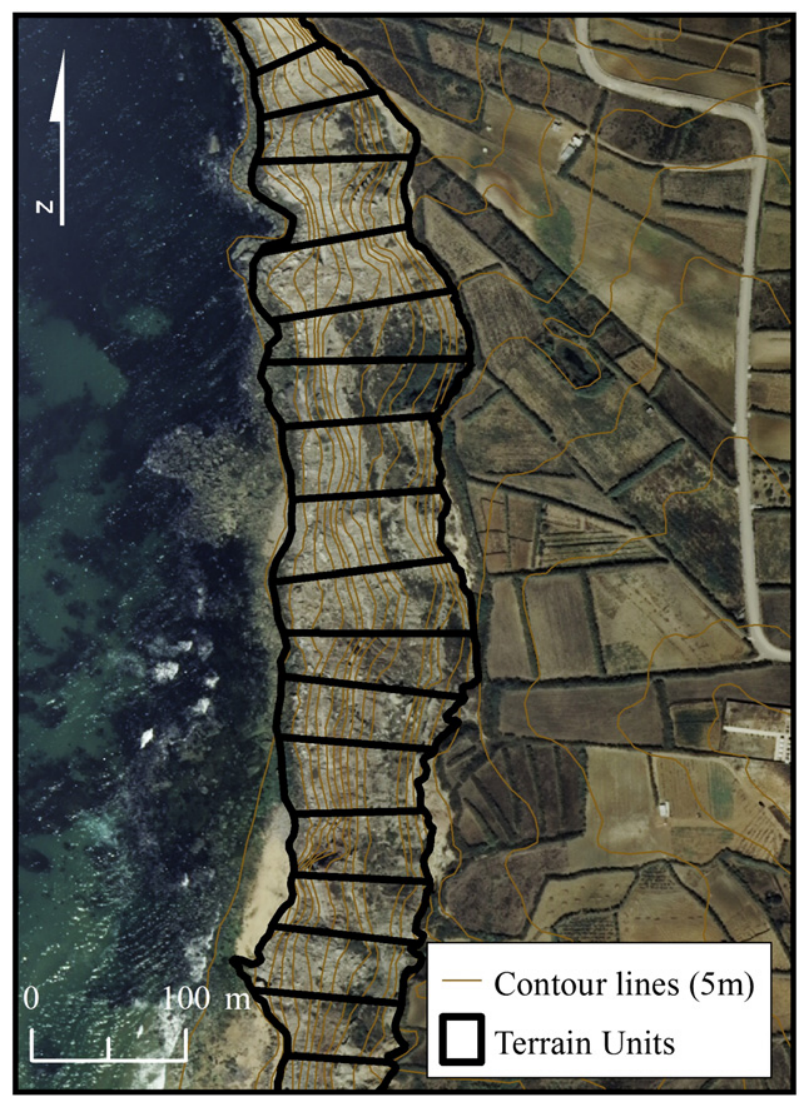

Fig. 5. A stretch of the Lourinhã coastal area divided in terrain units.

\subsection{Landslide susceptibility models}

Landslide susceptibility models enable the classification of a study area concerning the spatial probability of occurrence of new slope movements. These models use the spatial relationship between predisposing factors and the distribution of past landslides to predict the probable location of future landslides. In this study, models were developed using a bi-variate statistical method: the Information Value (Yin and Yan, 1988). With this method, each class of each landslide predisposing factor is considered as an independent variable. The method weights each independent variable based on the relationship between the variable spatial occurrence and the occurrence of cliff failure, which is the dependent variable of the system. Thus, the susceptibility assessment is based on the spatial distribution of both independent variables and dependent variable (Marques et al., 2011). The Information Value (Ii) for each variable $(x i)$ was calculated using the following equation (Yin and Yan, 1988):

$I i=\log \frac{S i / N i}{S / N}$

where $S i$ is the number of terrain units with landslides of given type within variable $x i$; $\mathrm{Ni}$ is the number of terrain units with the variable $x i ; S$ is the number of terrain units with landslides of given type; and $N$ is the total number of terrain units in the study area.

While negative $I i$ values indicate that the presence of variable $X i$ is not favorable to landslide occurrence, positive $I i$ values indicate that a positive relationship exists between the presence of variable $X i$ and the occurrence of landslides, which increase proportionally with the increasing of score. When $\mathrm{Si}$ is zero, $\mathrm{Ii}$ is not possible to obtain due to the log normalization. In such case, $I i$ was forced to be the first decimal lower than the lowest Ii obtained within the considered landslide predisposing factor.

The total Information Value $(I j)$ for a terrain unit $j$ was computed as follows (Yin and Yan, 1988):

$I j=\sum_{i=1}^{n} X j i \cdot I i$

where $n$ is the number of variables, and $X j i$ is either 0 or 1 , if the variable is not present or present in the terrain unit $j$, respectively.

Susceptibility models (in this case considered as predictive models) were individually developed for each landslide type, as well as for the complete set of landslides inventoried. Therefore, four landslide susceptibility models were built using half of the respective group of landslide occurrences selected randomly (modeling group) and validated with the other half (validation group).

Four susceptibility classes were defined for each susceptibility model according to the same Information Value scores $(I j)$ to enable 
Table 1

Information Value scores obtained for rotational slides, translational slides, debris flows and total landslides.

\begin{tabular}{|c|c|c|c|c|c|c|}
\hline \multirow[t]{2}{*}{ Variables } & \multirow[t]{2}{*}{ Classes } & \multirow[t]{2}{*}{ Terrain units } & \multicolumn{4}{|c|}{ Information Value scores } \\
\hline & & & Rotational slides & Translational slides & Debris flows & Total landslides \\
\hline \multirow[t]{6}{*}{ Cliff elevation (m) } & $<30$ & 35 & -0.497 & -0.165 & -0.012 & -0.268 \\
\hline & $30-40$ & 43 & -0.397 & -0.065 & 0.088 & 0.018 \\
\hline & $40-50$ & 64 & 0.051 & 0.056 & 0.100 & 0.007 \\
\hline & $50-60$ & 63 & 0.117 & -0.231 & 0.028 & 0.061 \\
\hline & $60-70$ & 32 & 0.153 & 0.292 & -0.338 & 0.025 \\
\hline & $>70$ & 24 & 0.345 & -0.331 & -0.072 & 0.060 \\
\hline \multirow[t]{7}{*}{ Mean slope angle $\left({ }^{\circ}\right)$} & $<25$ & 23 & -0.330 & -0.115 & 0.053 & -0.125 \\
\hline & $25-30$ & 48 & -0.029 & -0.115 & 0.023 & 0.006 \\
\hline & $30-32.5$ & 35 & 0.162 & -0.245 & -0.444 & -0.040 \\
\hline & $32.5-35$ & 47 & 0.080 & 0.195 & 0.148 & 0.155 \\
\hline & $35-40$ & 56 & 0.086 & -0.193 & 0.131 & 0.056 \\
\hline & $40-45$ & 37 & -0.029 & 0.016 & -0.357 & -0.125 \\
\hline & $>45$ & 15 & -0.430 & -0.084 & -0.457 & -0.087 \\
\hline \multirow[t]{7}{*}{ Maximum slope angle $\left({ }^{\circ}\right)$} & $<50$ & 23 & -0.352 & 0.186 & 0.075 & -0.074 \\
\hline & $50-55$ & 43 & -0.120 & -0.377 & 0.023 & -0.025 \\
\hline & $55-60$ & 69 & 0.035 & 0.023 & 0.092 & 0.020 \\
\hline & $60-65$ & 52 & 0.109 & -0.435 & 0.011 & 0.067 \\
\hline & $65-70$ & 37 & 0.133 & -0.009 & -0.148 & -0.084 \\
\hline & $70-75$ & 29 & -0.391 & 0.343 & -0.095 & 0.011 \\
\hline & $>75$ & 8 & 0.302 & 0.401 & -0.482 & 0.051 \\
\hline \multirow[t]{7}{*}{ Standard deviation slope angle $\left({ }^{\circ}\right)$} & $<9$ & 34 & 0.033 & 0.317 & 0.137 & 0.041 \\
\hline & $9-10.5$ & 48 & 0.011 & -0.426 & 0.154 & 0.000 \\
\hline & $10.5-12$ & 35 & 0.193 & -0.526 & 0.054 & 0.045 \\
\hline & $12-13.5$ & 33 & -0.029 & 0.085 & 0.033 & -0.087 \\
\hline & $13.5-15$ & 37 & -0.220 & -0.009 & 0.053 & 0.064 \\
\hline & $15-18$ & 42 & 0.056 & 0.133 & -0.069 & -0.063 \\
\hline & $>18$ & 32 & -0.175 & 0.277 & -0.374 & 0.000 \\
\hline \multirow[t]{3}{*}{ Profile slope curvature } & Concave & 186 & 0.011 & 0.045 & -0.013 & 0.000 \\
\hline & Straight & 15 & -0.140 & -0.354 & 0.000 & -0.176 \\
\hline & Convex & 60 & 0.021 & -0.040 & 0.100 & 0.035 \\
\hline \multirow[t]{3}{*}{ Plan slope curvature } & Convergent & 97 & 0.068 & -0.254 & 0.023 & 0.027 \\
\hline & Planar & 14 & -0.372 & 0.100 & -0.278 & -0.222 \\
\hline & Divergent & 150 & -0.026 & 0.107 & 0.003 & 0.000 \\
\hline \multirow[t]{5}{*}{ Potential solar radiation $\left(\mathrm{kWh} / \mathrm{m}^{2}\right)$} & $<950$ & 47 & -0.165 & 0.236 & -0.069 & -0.051 \\
\hline & $950-1025$ & 43 & -0.096 & -0.076 & 0.217 & -0.018 \\
\hline & $1025-1100$ & 59 & 0.135 & -0.032 & 0.110 & 0.051 \\
\hline & $1100-1175$ & 62 & 0.112 & -0.231 & -0.105 & 0.000 \\
\hline & $>1175$ & 50 & -0.129 & 0.052 & 0.144 & -0.008 \\
\hline \multirow[t]{6}{*}{ Lithological units } & LU1 & 146 & 0.034 & -0.285 & -0.091 & -0.016 \\
\hline & LU2 & 6 & -0.029 & 0.493 & 0.120 & 0.016 \\
\hline & LU3 & 25 & -0.138 & -0.040 & 0.208 & -0.039 \\
\hline & LU1-LU2 & 18 & 0.369 & -0.385 & -0.191 & 0.176 \\
\hline & LU1-LU3 & 60 & 0.050 & -0.385 & -0.191 & 0.125 \\
\hline & LU2-LU3 & 6 & -0.238 & -0.140 & 0.108 & 0.079 \\
\hline \multirow[t]{3}{*}{ Geologic structure } & 0 to $5^{\circ}-$ North & 161 & 0.107 & -0.239 & 0.029 & 0.029 \\
\hline & 0 to $5^{\circ}-$ South & 23 & -0.154 & -0.096 & 0.094 & 0.051 \\
\hline & 5 to $15^{\circ}-$ South & 77 & -0.253 & 0.292 & -0.431 & -0.114 \\
\hline
\end{tabular}

model comparison: Low ( $\mathrm{Ij}$ less than -0.5 ); Moderate ( $\mathrm{Ij}$ between -0.5 and 0 ); High ( $I j$ between 0 and 0.5 ); and Very high ( $I j$ higher than 0.5 ).

The Effectiveness Ratio proposed by Chung and Fabbri (2003) was used to assess the performance and predictive power of susceptibility models by comparing the proportion of unstabilized area in each susceptibility class $(\mathrm{AL})$ with a proportion of the susceptibility class in the entire study area (AS). With these terms, the ratio AL/AS is used to define "effective" and "very effective" susceptibility classes. To be considered a powerful and effective prediction class, the ratio should be near zero in classes of low susceptibility and very large in classes of high and very high susceptibilities (Chung and Fabbri, 2003). This method has been developed for matrix models, for which it was considered

Table 2

Accountability (A) and Reliability (R) indexes for the different predisposing factors used for the susceptibility model construction.

\begin{tabular}{|c|c|c|c|c|c|c|c|c|}
\hline \multirow[t]{2}{*}{ Predisposing factors } & \multicolumn{2}{|c|}{ Rotational slides } & \multicolumn{2}{|c|}{ Translational slides } & \multicolumn{2}{|c|}{ Debris flows } & \multicolumn{2}{|c|}{ Total landslides } \\
\hline & A & $\mathrm{R}$ & A & $\mathrm{R}$ & A & $\mathrm{R}$ & A & $\mathrm{R}$ \\
\hline Cliff elevation & 0.935 & 0.295 & 0.500 & 0.079 & 0.736 & 0.445 & 0.913 & 0.725 \\
\hline Maximum slope angle & 0.652 & 0.273 & 0.429 & 0.076 & 0.819 & 0.472 & 0.683 & 0.774 \\
\hline Mean slope angle & 0.783 & 0.269 & 0.714 & 0.083 & 0.792 & 0.429 & 0.644 & 0.720 \\
\hline Standard deviation slope angle & 0.717 & 0.252 & 0.786 & 0.085 & 0.792 & 0.435 & 0.740 & 0.713 \\
\hline Profile slope curvature & 0.978 & 0.221 & 0.786 & 0.063 & 0.306 & 0.407 & 1.000 & 0.680 \\
\hline Plan slope curvature & 0.435 & 0.250 & 0.786 & 0.072 & 0.972 & 0.389 & 0.962 & 0.685 \\
\hline Potential solar radiation & 0.587 & 0.284 & 0.500 & 0.080 & 0.694 & 0.459 & 0.510 & 0.707 \\
\hline Lithological units & 0.783 & 0.240 & 0.214 & 0.176 & 0.417 & 0.545 & 0.240 & 0.625 \\
\hline Geologic structure & 0.761 & 0.273 & 0.571 & 0.111 & 0.764 & 0.414 & 0.808 & 0.718 \\
\hline
\end{tabular}


that the ratio of "effective" susceptibility classes should be either higher than 3 (for high susceptibility classes) or lower than 0.2 (for low susceptibility classes), and the ratio of "very effective" susceptibility classes should be higher than 6 or lower than 0.1 . In the present work, we decided to use different values to define the threshold of the "effective" and "very effective" classes, taking into account the type of terrain unit used in this study. Thus, it was decided to reduce by $50 \%$ the features proposed by Chung and Fabbri (2003). Therefore, a susceptibility class is considered "effective" ("very effective") when the ratio is higher than 1.5 (3) for the high and very high susceptibility classes, and lower than $0.4(0.2)$ for the low susceptibility class.
The standard Receiver Operator Characteristic (ROC) (Egan, 1975; Swets, 1988) curves were used to assess the degree of fit and the predictive capacity of the landslide susceptibility models. ROC curves relate the proportion of unstable terrain units correctly classified as susceptible (true positive rate) with the proportion of stable terrain units classified as susceptible (false positive rate) (Frattini et al., 2010).

\section{Results and discussion}

The Accountability and Reliability indexes show that different landslide types are not conditioned in the same way by the same set of

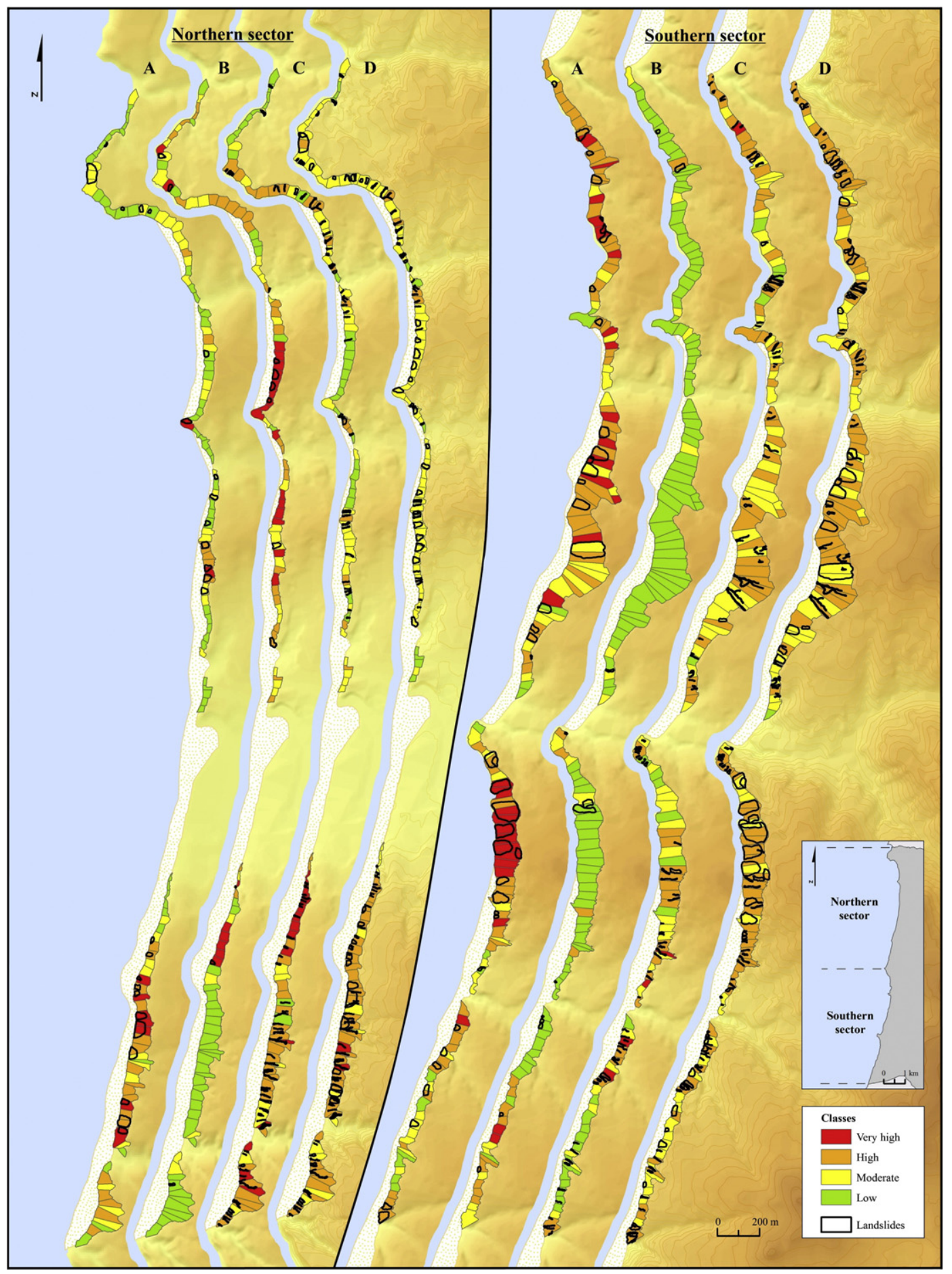

Fig. 6. Landslide susceptibility maps and respectively observed cliff failures. A - rotational slides; B - translational slides; C - debris flows; D - total landslides. 
landslide predisposing factors (Table 2). The predisposing factors most relevant to the occurrence of rotational slides are the profile slope curvature and cliff elevation, while for translational slides are the lithological units, geologic structure, standard deviation of slope angle and profile and plan slope curvatures. Finally, for debris flows the main predisposing factors are the plan slope curvature, mean slope angle and lithological units (Table 2).

Table 1 summarizes the Information Values obtained for landslide predisposing factor classes taking into account the four considered landslide groups: rotational slides, translational slides, debris flows and total landslides. Some predisposing classes (e.g. maximum slope angle above $60^{\circ}$ ) evidence very different scores for different types of landslides, which confirm that different landslide types are differently conditioned by the same set of independent variables.

The total landslide susceptibility score obtained for each terrain unit ( $\mathrm{Ij}$ ) showed different ranges for different landslide typologies: from -1.934 to 1.172 for rotational slides; from -2.898 to 1.542 for translational slides; from -1.740 to 1.000 for debris flows; and from -0.862 to 0.505 for the complete landslide inventory. The model produced for translational slides shows the highest range of susceptibility values, which means a high contrast between stable and unstable units. Therefore, uncertainty regarding the location of future landslides is the lowest in this model.

The landslide susceptibility models built for each type of landslide and for the total set of landslides (based on modeling group data) are shown in Fig. 6. The susceptibility models produced for rotational slides, translational slides and debris flows evidence significant differences concerning the spatial distribution of susceptibility classes, thus reflecting the abovementioned distinct influence of the landslide predisposing factors. In addition, the spatial distribution of each landslide typology has a good agreement with the corresponding higher landslide susceptibility classes. On the other hand, the susceptibility model built for the total landslides (Fig. 6D) does not agree with the other models (Fig. 6A, B and C) in spatial terms and is not able to correctly discriminate the terrain units more susceptible to landslide occurrence.

The ideal terrain conditions for the development of different types of landslides are summarized in Table 3. The ranking of the five main terrain conditions for landslide occurrence is based on the Information Value scores of landslide predisposing factor classes. Rotational slides preferentially occur in coastal cliffs that simultaneously cut lithological units LU1 and LU2, and where the cliff top elevation is higher than $70 \mathrm{~m}$, the maximum slope angle is higher than $75^{\circ}$ and the medium slope angle ranges from 30 to $32.5^{\circ}$. Translational slides are associated with coastal cliffs cut in lithological unit LU2, with a slope angle uniformly high (maximum slope angle higher than $70^{\circ}$; standard deviation of slope angle ranging from $5^{\circ}$ to $9^{\circ}$ ), wherein cliff top elevation ranges from 60 to $70 \mathrm{~m}$. Debris flows occur dominantly in coastal cliffs where potential solar radiation ranges from 950 to $1025 \mathrm{kWh} / \mathrm{m}^{2}$ (W-SW slope aspect) and from 1175 to $1360 \mathrm{kWh} / \mathrm{m}^{2}$ (N-NW slope aspect), cut in lithological unit LU3, with a mean slope angle ranging from 32.5 to $35^{\circ}$ and with a relatively regular slope (standard deviation of slope angle between 9 and $10.5^{\circ}$ ). Therefore, we verify that landslide occurrence is strongly influenced by variables related to slope angle and geology. The elevation of cliffs and the potential solar radiation (i.e. the slope aspect) are in the following rank positions of predisposing conditions for the cliff slope instability system. The slope angle and geology are the proxy variables that better express the physical forces acting on the slope instability system: the effective shear stress and the shear strength of the slope material. Also the elevation of the cliff is a proxy of the potential energy associated with the cliff. Finally, the potential solar radiation gives an indirect expression of the importance of structural disposition of rock materials and its relationship with the direction of cliff face, which is particularly important in the case of translational slides.

Comparing the previous results with the ideal conditions for the occurrence of landslides, considering the total set of landslides, we verify the inclusion of three new predisposing factor classes into the ranking: lithological units LU1-LU3 and LU2-LU3; and a maximum slope angle ranging from $60^{\circ}$ to $65^{\circ}$. The most important predisposing classes are lithological units LU1-LU2 and the mean slope angle between 32.5 and $35^{\circ}$. The first class is also observed in the ranking for rotational slides while the second class is also present in the ranking for debris flows.

Results of susceptibility models can also be analyzed through the relationship between landslide spatial distribution and landslide susceptibility classes. Fig. 7 shows the relative representation of both unstable and stable terrain units in each susceptibility class for the four landslide predictive models. The same tendency is evident within the four models: the proportion of unstable terrain units is maximum in classes of high and very high susceptibilities; in opposition, in classes of low and moderate susceptibilities the proportion of stable terrain units is maximum. According to Zêzere (2002), the validation of the method is confirmed when the majority of unstable terrain units concentrate in classes of high and very high susceptibilities. For each developed model, the following results were obtained (Fig. 7): (i) for rotational slides, 121 terrain units are classified as high or very high susceptibility and 66 ( $71.7 \%$ of total unstable terrain units) were affected by rotational slides in the past; (ii) for translational slides, 69 terrain units are classified as high or very high susceptibility and 19 (60.7\% of total unstable terrain units) were affected by translational slides in the past; (iii) for debris flows, 115 terrain units are classified as high or very high susceptibility and 80 (55.9\% of total unstable terrain units) were affected by debris flows in the past; (iv) for the total set of landslides, 123 terrain units are classified as high or very high susceptibility and 109 (52.2\% of total unstable terrain units) were affected by any landslide type in the past. Therefore, these results show that the best predictive model is the one generated for rotational slides, while the worst predictive model is the one generated for the total set of landslides.

The Effectiveness Ratio (Fig. 8) indicates that the developed models separate reasonably well the lower from the higher susceptibility classes. In total, there are four "effective" classes and one "very effective" class: the rotational slide model has two "effective" susceptibility classes (Low and Very high classes); the translational slide model has one "effective" class (High) and one "very effective" class (Very high); and

Table 3

Ranking of ideal terrain conditions for landslide occurrence based on Information Value.

\begin{tabular}{|c|c|c|c|c|}
\hline Ranking & Rotational slides & Translational slides & Debris flows & Total landslides \\
\hline $1^{\circ}$ & $\begin{array}{l}\text { LU1-LU2 } \\
\text { (lithological unit) }\end{array}$ & $\begin{array}{l}\text { LU2 } \\
\text { (lithological unit) }\end{array}$ & $\begin{array}{l}950-1025 \mathrm{kWh} / \mathrm{m}^{2} \\
\text { (potential solar radiation) }\end{array}$ & $\begin{array}{l}\text { LU1-LU2 } \\
\text { (lithological unit) }\end{array}$ \\
\hline $2^{\circ}$ & $\begin{array}{l}>70 \mathrm{~m} \\
\text { (cliff elevation) }\end{array}$ & $\begin{array}{l}>75^{\circ} \\
\text { (maximum slope angle) }\end{array}$ & $\begin{array}{l}\text { LU3 } \\
\text { (lithological unit) }\end{array}$ & $\begin{array}{l}32.5-35^{\circ} \\
\text { (mean slope angle) }\end{array}$ \\
\hline $3^{\circ}$ & $\begin{array}{l}>75^{\circ} \\
\text { (maximum slope angle) }\end{array}$ & $\begin{array}{l}70-75^{\circ} \\
\text { (maximum slope angle) }\end{array}$ & $\begin{array}{l}9-10.5^{\circ} \\
\text { (standard deviation slope angle) }\end{array}$ & $\begin{array}{l}\text { LU1-LU3 } \\
\text { (lithological unit) }\end{array}$ \\
\hline $4^{\circ}$ & $\begin{array}{l}10.5-12^{\circ} \\
\text { (standard deviation slope angle) }\end{array}$ & $\begin{array}{l}5-9^{\circ} \\
\text { (standard deviation slope angle) }\end{array}$ & $\begin{array}{l}32.5-35^{\circ} \\
\text { (mean slope angle) }\end{array}$ & $\begin{array}{l}\text { LU2-LU3 } \\
\text { (lithological unit) }\end{array}$ \\
\hline $5^{\circ}$ & $\begin{array}{l}30-32.5^{\circ} \\
\text { (mean slope angle) }\end{array}$ & $\begin{array}{l}60-70 \mathrm{~m} \\
\text { (cliff elevation) }\end{array}$ & $\begin{array}{l}1175-1360 \mathrm{kWh} / \mathrm{m}^{2} \\
\text { (potential solar radiation) }\end{array}$ & $\begin{array}{l}60-65^{\circ} \\
\text { (maximum slope angle) }\end{array}$ \\
\hline
\end{tabular}


A

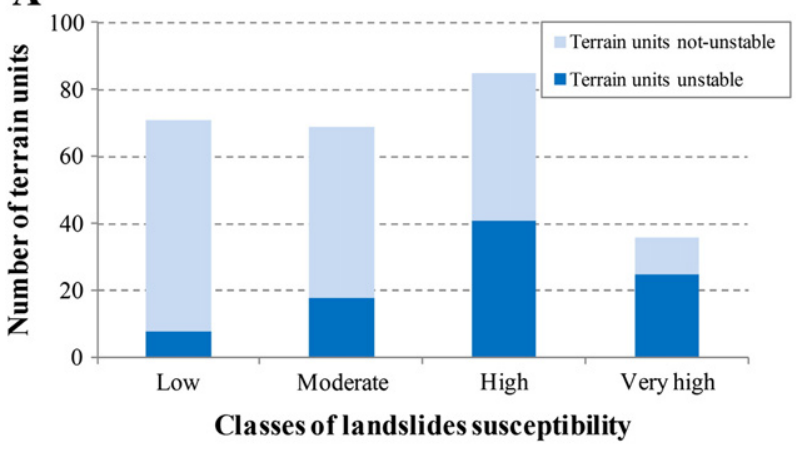

C

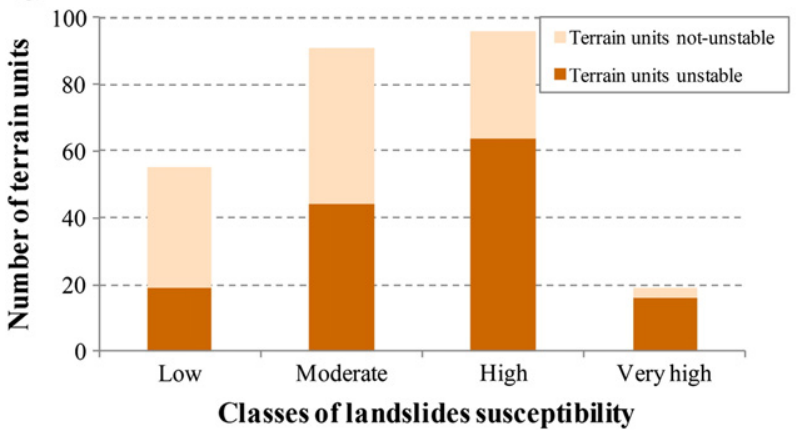

B

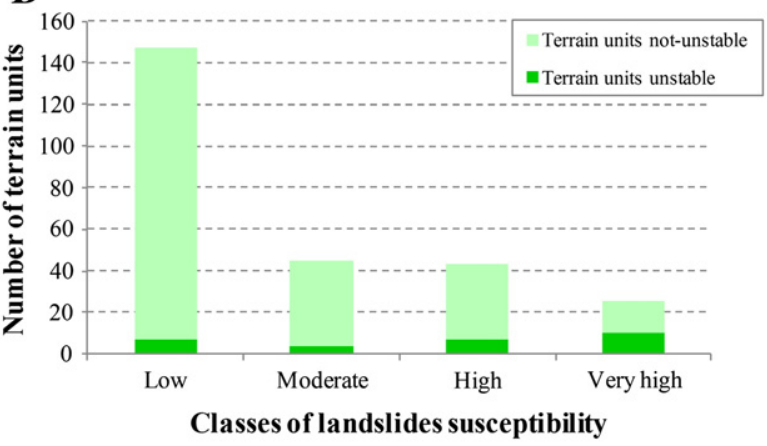

D

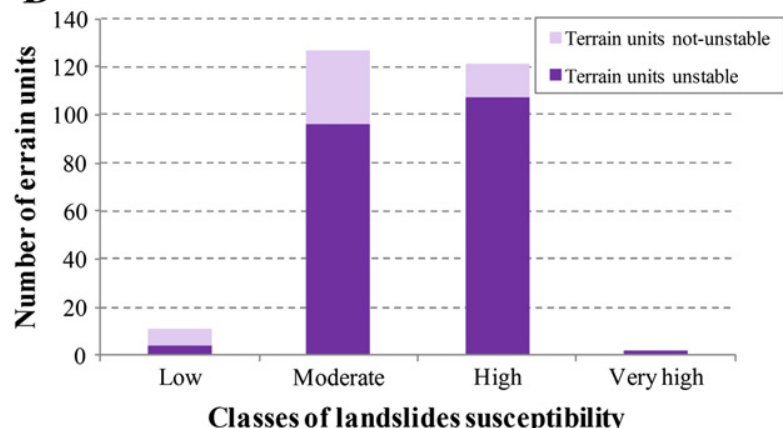

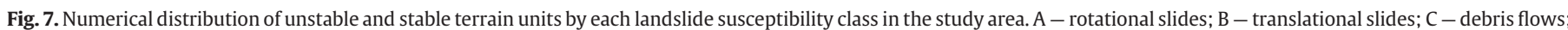
D - total landslides.

the debris flow model has one "effective" class (Very high). In these cases, the performance and predictive ability of the models in determining the location with the highest probability of occurrence of landslide is considered strong. In contrast, the susceptibility model built with the total set of landslides (i.e. not accounting the landslide types) did not generate any "effective" or "very effective" susceptibility class, which proves the poor ability of this model to predict the location of future landslides.

The landslide susceptibility models were validated by computing predictive ROC curves (Fig. 9), and the following Area Under Curve (AUC) values were obtained: rotational slides, 0.703; translational slides, 0.674; debris flows, 0.634 ; and total landslides, 0.614 . These results show that susceptibility models have an acceptable predictive skill. In addition, again, results highlight the better performance of predictive models built for each type of landslide in comparison with the model built for the total set of landslides.

\section{Conclusions}

The Information Value Method revealed to be appropriate and capable to assess landslide susceptibility in coastal cliffs in the study area. This method discriminates in an acceptable way the presence/absence

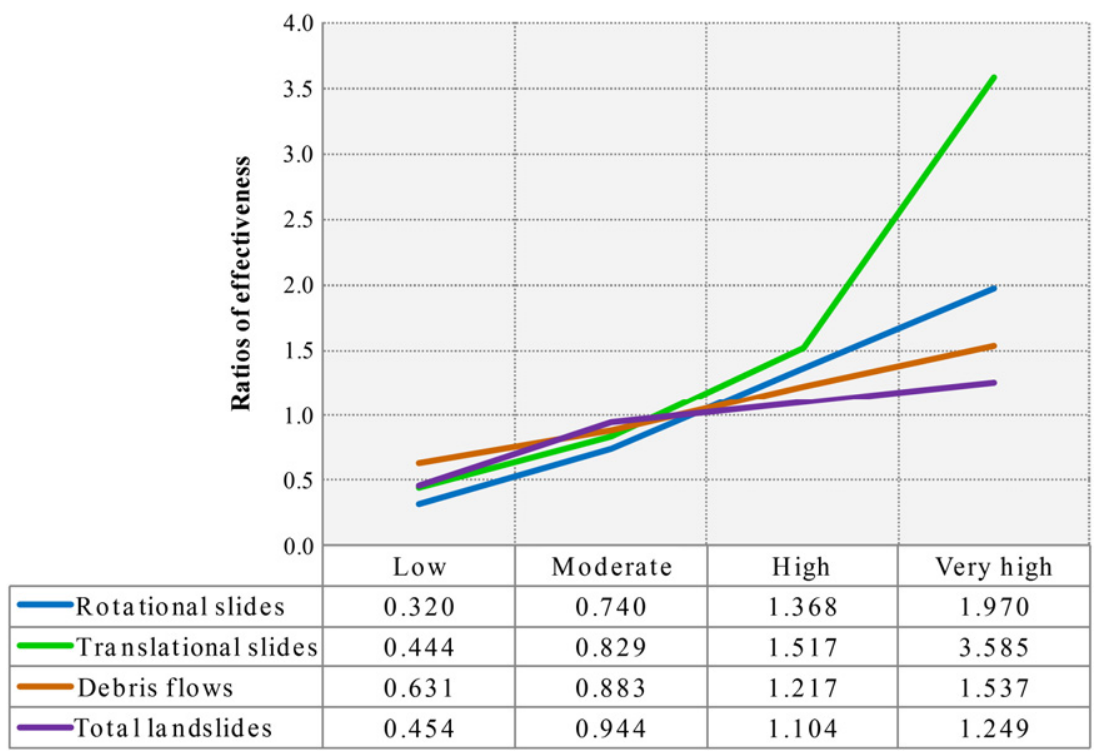

Fig. 8. Effectiveness Ratio for susceptibility classes. 


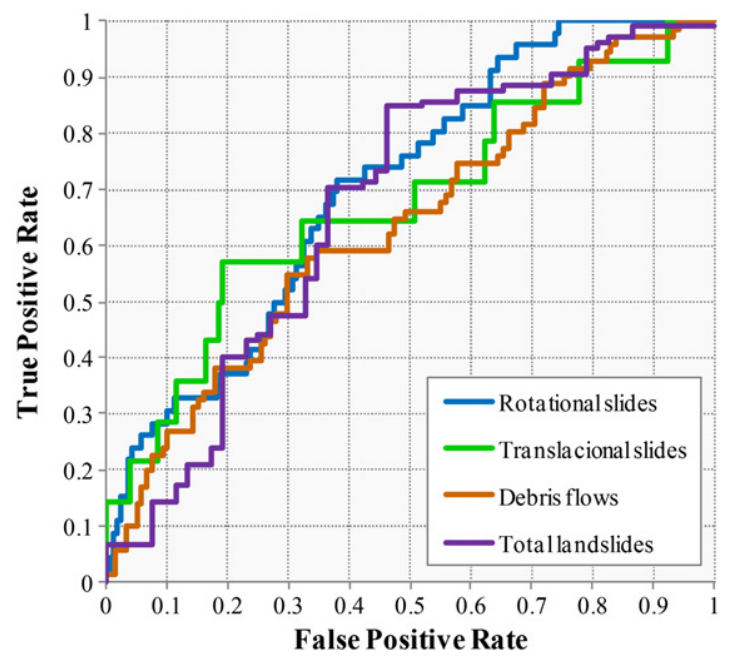

Fig. 9. ROC curves of the landslide susceptibility models. Rotational slides, 0.703 ; translational slides, 0.674; debris flows, 0.634; and total landslides, 0.614 .

of landslides with the considered landslide predisposing factors. In addition, the Information Value scores enabled the identification of variables that strongly influence landslide occurrence in the study area: geological units and slope angle.

In very steep coastal cliffs dominated by rockfalls, topples and planar rock slides it is almost impossible to distinguish different landslide types that occurred in the past. Therefore, in previous studies developed in these environments, landslide susceptibility has been assessed considering the set of landslides that occurred not accounting landslide typology (e.g. Marques et al., 2011). The coastal cliffs in the study area exhibit particular conditions related with the relatively low slope angle, which enable the easier identification of landslide types. In such circumstances, we demonstrated in this study that susceptibility results improve substantially when the predictive models are developed for each typology of landslide. The physical conditions that control the activity of each landslide type are not the same, and these justify the different relationships between the spatial distribution of each landslide type and the set of landslide predisposing factors.

Predictive models developed for each type of landslide can be an asset for land use planning and management in order to increase the reliability of the susceptibility assessment. Moreover, the magnitude and damaging potential may be quite different for different types of landslides. Furthermore, the technical strategies to mitigate landslide activity also depend on landslide typology (Zêzere, 2002), and these are further reasons to discriminate between different types of landslides, whenever possible, when assessing landslide susceptibility in coastal cliffs.

\section{References}

Blahut, J., Westen, C., Sterlacchini, S., 2010. Analysis of landslide inventories for accurate prediction of debris-flow sources areas. Geomorphology 119, 36-51.

Carrara, A., Guzzetti, F., Cardinalli, M., Reichenbach, P., 1998. Current limitations in modeling landslide hazard. In: Buccianti, A., Nardi, G., Potenza, R. (Eds.), Proceedings of the International Association for Mathematical Geology '98, 4, pp. 195-203.

Carrara, A., Crosta, G.B., Frattini, P., 2008. Comparing models of debris-flow susceptibility in the alpine environment. Geomorphology 94, 353-378.

Chung, C.F., Fabbri, A.G., 2003. Validation of spatial prediction models for landslide hazard mapping. Nat. Hazards 30, 451-472.

Cruden, D.M. Varnes, D.J 1996. Landslide types and processes. In: Turner, A.K. Schuster, R.L. (Eds.), Landslide, Investigation and Mitigation. Spatial Report, 247. Transportation Research Council, National Academy Press, Washington DC, pp. 36-75.

Daveau, S., 1988. O clima. Comentários e actualizações. In: Ribeiro, O., Lautensach, H. Daveau, S. (Eds.), Geografia de Portugal. João Sá da Costa Editions, pp. 387-464.

Dikau, R., Brunsden, D., Schrott, L., Ibson, M.L., 1996. Landslide Recognition: Identification, Movement and Causes. John Wiley \& Sons, Chichester, UK.

Egan, J.P., 1975. Signal Detection Theory and ROC Analysis. Academic Press, New York.
Epifânio, B., Zêzere, J.L., Neves, N., 2013. Identification of hazardous zones combining cliff retreat with landslide susceptibility assessment. In: Conley, D.C., Masselink, G., Russel, P.E., O'Hare, T.J. (Eds.), Proceedings 12th International Coastal Symposium (Plymouth, England). Journal of Coastal Research, SI, 65, pp. 1681-1686.

Frattini, P., Crosta, G., Carrara, A., 2010. Techniques for evaluating the performance of landslide susceptibility models. Eng. Geol. 111, 62-72.

Greenwood, R.O., Orford, J.D., 2007. Factors controlling the retreat of Drumlin coastal cliffs in a low energy marine environment - Strangford Lough, Northern Ireland. J. Coast. Res. 23, 285-297.

Guillard, C., Zêzere, J.L., 2012. Landslide susceptibility assessment and validation in framework of municipal planning in Portugal: the case of Loures municipality. Environ. Manag. 50, 721-735.

Guzzetti, F., Carrara, A., Cardinali, M., Reichenbach, P., 1999. Landslide hazard evaluation: a review of current techniques and their application in a multi-scale study, Central Italy. Geomorphology 31, 181-216.

Guzzetti, F., Reichenbach, P., Cardinali, M., Galli, M., Ardizzone, F., 2005. Probabilistic landslide hazard assessment at the basin scale. Geomorphology 72, 272-299.

Hampton, M.A., Griggs, G.B., Edil, T.B., Guy, D.E., Kelley, J.T., Komar, P.D., Mickelson, D.M., Shipman, H.M., 2004. Processes that govern the formation and evolution of coastal cliffs. In: Hampton, M.A., Griggs, G.B. (Eds.), Formation, Evolution, and Stability of Coastal Cliffs: Status and Trends. U.S. Geological Survey Professional Paper 1693, pp. 7-38.

Mancini, F., Ceppi, C., Ritrovato, G., 2010. GIS and statistical analysis for landslide susceptibility mapping in the Daunia area, Italy. Nat. Hazards Earth Syst. Sci. 10, 1851-1864.

Manuppella, G., Antunes, M.T., Pais, J., Ramalho, M.M., Rey, J., 1999. Notícia explicativa da folha 30-A (Lourinhã), Geologic map of Portugal, scale 1/50000. Instituto Geológico e Mineiro, Lisbon.

Marques, F., 1997. As arribas do litoral do Algarve. Dinâmica, processos e mecanismosUniversity of Lisbon, Lisbon, Portugal (Ph.D. thesis).

Marques, F., 2009. Sea cliff instability hazard prevention and planning: examples of practice in Portugal. J. Coast. Res. SI 56, 856-860.

Marques, F., Matildes, R., Redweik, P., 2011. Statistically based sea cliff instability hazard assessment of Burgau-Lagos coastal section (Algarve, Portugal). J. Coast. Res. SI 64, 927-931.

Marques, F.M.S.F., Matildes, R., Redweik, P., 2013. Sea cliff instability susceptibility at regional scale: a statistically based assessment in the Southern Algarve, Portugal. Nat. Hazards Earth Syst. Sci. 13, 3185-3203.

Neves, M., 2004. Evolução actual dos litorais rochosos da estremadura norte. Estudo de geomorfologiaUniversity of Lisbon, Lisbon, Portugal (Ph.D. thesis).

Neves, M., Ramos-Pereira, A., 1999. The interaction between marine and sub-aerial processes in the evolution of rocky coasts: the example of Castelejo (southwest Portugal). Bol. Inst. Esp. Oceanogr. 15, 251-258.

Neves, M., Zêzere, J.L., Henriques, C., Garcia, R., Oliveira, S., Piedade, A., 2012. Modelling the long term evolution of rocky coasts in central Portugal. Avances de la Geomorfología en España. Actas de la XII Reunión Nacional de Geomorfología pp. 73-76.

Nunes, M., Ferreira, Ó., Schaefer, M., Clifton, J., Baily, B., Moura, D., Loureiro, C., 2009. Hazard assessment in rock cliffs at Central Algarve (Portugal): a tool for coastal management. Ocean Coast. Manage. 52, 506-515.

Pires, H., 1989. O Clima de Portugal. Alguns aspectos do clima de agitação marítima de interesse para a navegação na costa de Portugal. Instituto Nacional de Meteorologia e Geofísica, Lisbon.

Sunamura, T., 1992. Geomorphology of Rocky Coast. John Wiley \& Sons.

Swets, J.A., 1988. Measuring the accuracy of diagnostic systems. Science 240, 1285-1293.

Teixeira, S., 2006. Slope mass movements on rocky sea-cliffs: a power-law distributed natural hazard on the Barlavento Coast, Algarve, Portugal. Cont. Shelf Res. 26, 1077-1091.

Trenhaile, A.S., 1987. The Geomorphology of Rocky Coasts. Clarendon Press, Oxford.

Van Den Eeckhaut, M., Reichenbach, P., Guzzetti, F., Rossi, M., Poesen, J., 2009. Combined landslide inventory and susceptibility assessment based on different mapping units: an example from the Flemish Ardennes, Belgium. Nat. Hazards Earth Syst. Sci. 9, 507-521.

Varnes, D.J., 1978. Slope movement types and processes. In: Schuster, R.L., Krizek, R.J. (Eds.), Landslides, Analysis and Control. Transportation Research Board Special Report, 176, Washington D.C., pp. 11-33.

Varnes, D.J., 1984. International Association of Engineering Geology Commission on Landslides and Other Mass Movements on Slopes. Landslide Hazard Zonation: A Review of Principles and PracticeUNESCO, Paris.

WP/WLI - International Geotechnical Societies' UNESCO (Working Party on World Landslide Inventory), 1993. Multilingual Landslide Glossary. Bitech Publisher, Richmond, British Columbia, Canada.

Yin, K.L., Yan, T.Z., 1988. Statistical prediction models for slope instability of metamorphosed rocks. In: Bonnard, C. (Ed.), Proceedings of the 5th International Symposium on Landslides (Lausanne, Switzerland), 2, pp. 1269-1272.

Zêzere, J.L., 1997. Movimentos de Vertente e Perigosidade Geomorfológica na Região a Norte de Lisboa. University of Lisbon, Lisbon, Portugal (Ph.D. thesis).

Zêzere, J.L., 2002. Landslide susceptibility assessment considering landslide typology. A case study in the area north of Lisbon (Portugal). Nat. Hazards Earth Syst. Sci. 2, 73-82.

Zêzere, J.L., 2005. Dinâmica de vertentes e risco geomorfológico. Centro de Estudos Geográficos, Report 41, Lisbon.

Zêzere, J.L., Reis, E., Garcia, R., Oliveira, S., Rodrigues, M.L., Vieira, G., Ferreira, A.B., 2004. Integration of spatial and temporal data for the definition of different landslide hazard scenarios in the area north of Lisbon (Portugal). Nat. Hazards Earth Syst. Sci. $4,133-146$. 